\title{
Development and characterization of new polymorphic microsatellite markers for Eurasian ground squirrel Spermophilus fulvus (Lichtenstein, 1823)
}

\author{
Sergey V. Titov, Olga N. Batova, Nina A. Vasilieva, Ludmila E. Savinetskaya \\ \& Andrey V. Tchabovsky*
}

\begin{abstract}
Ground squirrels are ecosystem engineers and keystone species in many open landscapes of Eurasia, America, and Africa. They are model objects for population studies, behavioural ecology, life-history theory, and conservation biology, the research areas where microsatellite analysis is widely applied and fruitful. So far, microsatellite markers have been developed for only few Palearctic ground squirrels. We tested and characterized 14 markers previously developed for ground squirrels and 10 new loci with tri-, tetra-, and five-nucleotide repeats in the yellow ground squirrel, Spermophilus fulvus, a species widely distributed in Eurasia and endangered in some regions. We found polymorphism in 10 loci, five of them were highly polymorphic (5-14 alleles). These markers will benefit studies of the population genetic structure, parentage, mating system, reproductive success, and interspecific hybridization as well as conservation efforts in S. fulvus and other close-related Eurasian ground squirrels.
\end{abstract}

How to cite this article: Titov S.V., Batova O.N., Vasilieva N.A., Savinetskaya L.E., Tchabovsky A.V. 2020. Development and characterization of new polymorphic microsatellite markers for Eurasian ground squirrel Spermophilus fulvus (Lichtenstein, 1823) // Russian J. Theriol. Vol.19. No.2. P.131-135. doi: 10.15298/ rusjtheriol.19.2.03.

KEY WORDS: microsatellite markers, primers, polymorphic loci, ground squirrels, Spermophilus fulvus, Sciuridae.

Sergey V. Titov [svtitov@yandex.ru], Department of Zoology and Ecology, Penza State University, 40, Krasnaya str., Penza 440026, Russia; Olga N. Batova [batova_olga@mail.ru], Nina A. Vasilieva [ninavasilieva@gmail.com], Ludmila E. Savinetskaya [ligen54@mail.ru], AndreyV.Tchabovsky [tchabovsky@gmail.com], Laboratory for Population Ecology, A.N. Severtsov Institute of Ecology and Evolution Russian Academy of Sciences, 33, Leninskii prospect, Moscow 119071, Russia.

\section{Разработка и характеристика новых полиморфных микросателлитных маркеров для Евразийского вида наземных беличьих Spermophilus fulvus (Lichtenstein, 1823)}

\section{С.В. Титов, О.Н. Батова, Н.А. Васильева, Л.Е. Савинецкая, А.В. Чабовский*}

РЕЗЮМЕ. Наземные беличьи относятся к числу экосистемных инженеров и ключевых видов открытых ландшафтов Евразии, Америки и Африки. Они служат модельными объектами в популяционной биологии, поведенческой экологии, теории жизненных циклов и природоохранной науке - областях, в которых широко и плодотворно применяют микросателлитный анализ. Однако до сих пор микросателлитные маркеры были разработаны лишь для единичных представителей Палеарктических наземных беличьих. Мы протестировали 14 маркеров, разработанных ранее для наземных беличьих, и 10 новых локусов с три-, тетра- и пентануклиотидными повторами на желтом суслике Spermophilus fulvus. Этот вид широко распространен в Евразии, однако в некоторых регионах его численность сокращается, и он находится под угрозой исчезновения. Полиморфизм был обнаружен в 10 локусах, пять из них оказались высоко полиморфными (5-14 аллелей). Эта система маркеров может быть использована в исследованиях генетической структуры популяций, родства и отцовства, брачных отношений, репродуктивного успеха, межвидовой гибридизации, а также в природоохранных целях для желтого суслика и других близко родственных ему видов Евразийских наземных беличьих.

КЛЮЧЕВЫЕ СЛОВА: микросателлитные маркеры, праймеры, желтый суслик, Spermophilus fulvus, наземные беличьи, Sciuridae.

* Corresponding author 


\section{Introduction}

Ground squirrels are ecosystem engineers and keystone species in many open landscapes of Eurasia, America, and Africa (Thorington et al., 2012). They are very sensitive to landscape changes and fragmentation caused by human impact and endangered in many regions of the world. Ground squirrels are model objects for population genetics studies, behavioural ecology, life-history theory, and conservation biology, the research areas where microsatellite analysis is widely applied and fruitful. So far, microsatellite markers have been developed mainly for American species and only few for Palearctic ground squirrels: Spermophilus citellus (Linnaeus, 1766), S. suslicus (Güldenstaedt, 1770), and Marmota marmota (Linnaeus, 1758) (Hanslik \& Kruckenhauser, 2000; Gondek et al., 2006), all three representing European fauna.

Yellow ground squirrel, Spermophilus fulvus (Lichtenstein, 1823), is widely distributed in Asia and Southern European Russia. It inhabits dry steppes, semi-deserts, and deserts of Southern Russia, Central Asia, Kazakhstan, northern Iran and Afghanistan, and north-western China (Kucheruk, 1998). In Russia, it inhabits a narrow zone at the northeastern part of its range in the dry steppes on the left bank of the lower Volga River. Decreased grazing caused by the reduction of the livestock in 1990-2000s combined with ploughing of dry steppes caused landscape fragmentation, habitat loss, population decline, and extinction of some colonies (Oparin et al., 2004; Shilova et al., 2015). The expansion of the sister species $S$. major (Pallas, 1778) to the south has led to the formation of stable hybrid zones with $S$. fulvus expanding with time (Titov et al., 2006). S. fulvus is listed as vulnerable or endangered in the regional Red Data Books in Russia (the Republic of Kalmykia and Saratovskaya Oblast'). In our long-term individually-based study of $S$. fulvus we aim at understanding ecological and evolutionary causes of variation in male and female mating tactics and lifetime reproductive success as well as population dynamics and species distribution (Vasilieva \& Tchabovsky, 2015; 2018; Shilova et al., 2015). To achieve these goals as well as to contribute to conservation efforts in S. fulvus and other Eurasian ground squirrels, in this study, we tested and characterized previously known for other ground squirrel species as well as novel polymorphic microsatellites in S. fulvus.

\section{Methods}

Genomic DNA was extracted from ethanol-preserved ear tissue of adult presumably unrelated $S$. fulvus (both males and females) from the colony in Saratovskaya Oblast'. Dried tissue was digested overnight at $50^{\circ} \mathrm{C}$ with $17-20 \mu \mathrm{l}$ of proteinase $\mathrm{K}(20 \mu \mathrm{g} / \mu \mathrm{l})$, and DNA was extracted using a standard phenol-chloroform extraction method.

To design primers for 10 novel microsatellite loci, we analyzed manually the genome sequence of the thirteen-lined ground squirrel, Ictidomys tridecemlineatus (Mitchill, 1821) (GenBank Acc. No. AC192323) to identify tri-, tetra-, and five-nucleotide microsatellite repeats. We have chosen sequence fragments with eight or more perfect repeats and sufficient flanking sequence for further use. Primers were designed in such a way as to provide a range of product sizes useful to electrophoretic analysis. We modified primers previously designed for other ground squirrel species to shorten microsatellite sequence fragments for better separation of the alleles in gel electrophoresis.

Microsatellite polymerase chain reaction amplifications for all loci were carried out in T100 Thermal Cycler, BioRad in 25- $\mu$ l reaction volumes containing $0.1-0.2 \mu \mathrm{g}$ of template DNA, $15 \mathrm{pmol}$ of each primer, the mixture of four dNTP $(200 \mu \mathrm{M}$ of each), $2 \mathrm{mM}$ $\mathrm{MgCl}_{2}, 2$ units of recombinant Taq polymerase of low concentration, and $1 \times$ PCR buffer $\left(20 \mathrm{mM}\left(\mathrm{NH}_{4}\right)_{2} \mathrm{SO}_{4}\right.$, $50 \mathrm{mM}$ Tris-HCL(pH 8.9), $20 \mu \mathrm{M}$ EDTA, and $150 \mu \mathrm{g} / \mathrm{ml}$ bovine serum albumin). The optimal annealing temperature for each marker (the temperature with the highest PCR efficiency) was determined empirically using a gradient PCR protocol with temperatures set between 54 and $64^{\circ} \mathrm{C}$ with a $2^{\circ}$ gradient. PCR cycling conditions were 35 cycles of $94^{\circ} \mathrm{C}$ for $30 \mathrm{~s}, 58-60-62^{\circ} \mathrm{C}$ for $30 \mathrm{~s}$ (optimal annealing temperature, Table 1), $72^{\circ} \mathrm{C}$ for $30 \mathrm{~s}$. Microsatellite PCR products were electrophoresed and separated on a $8 \%$ polyacrylamide gel with size marker pBR322/Hpa II to determine the allele sizes. Fragments from polymorphic loci were sequenced on ABI PRISM 3500 (Thermo Fisher Scientific) genetic analyzer with a cycle sequencing kit (The BigDye ${ }^{\circledR}$ Terminator v3.1, $\mathrm{ABI}$ ) and same primers (used for PCR).

\section{Results and Discussion}

Out of 24 tested primer pairs, 17 amplified PCR products (Table 1). For two of 14 previously developed microsatellite markers (10 for three North-American ground squirrels, two for European ground squirrel, S. citellus, one for Urocitellus undulatus (Pallas, 1778), and one for $S$. fulvus), the product was not amplified, in four no polymorphism was found, while eight other were found polymorphic in S. fulvus. In addition to previously developed markers, we tested 10 novel loci with newly developed sets of primers. In five of them, no product was amplified, three were monomorphic, and two polymorphic. Thus, in total we found 10 variable loci with the number of alleles per locus ranging from two to seven. Five of them were highly polymorphic (five-seven alleles)

To characterize a set of 5 highly polymorphic markers in more detail, we tested them at a larger sample of 48 adult males and 38 adult females (Table 2 ). The product was amplified in all samples. MICRO-CHECKER 2.2.3 (van Oosterhout et al., 2004) revealed no evidence for sluttering, allele dropouts, or presence of a null allele at any locus. Allelic diversity ranged from 5 to 14 alleles/ locus (mean $=7.6$ ). Of the five microsatellites, one 


\begin{tabular}{|c|c|c|c|c|c|c|c|c|c|c|c|c|c|c|c|c|c|c|c|c|c|c|c|c|}
\hline 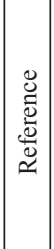 & 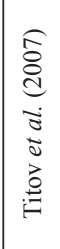 & 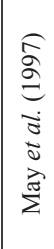 & 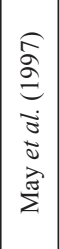 & 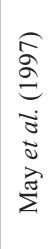 & 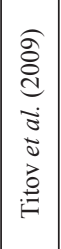 & 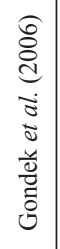 & 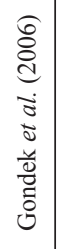 & 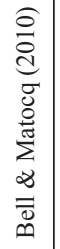 & 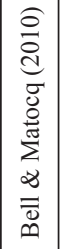 & 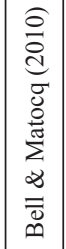 & 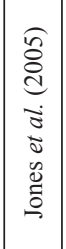 & 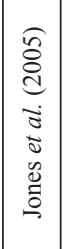 & 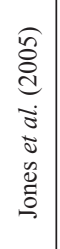 & 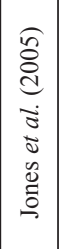 & $\vec{z}$ & 之 & 之 & $\vec{z}$ & $\vec{z}$ & 之 & $\vec{z}$ & 之 & 之 & $\dot{z}$ \\
\hline
\end{tabular}

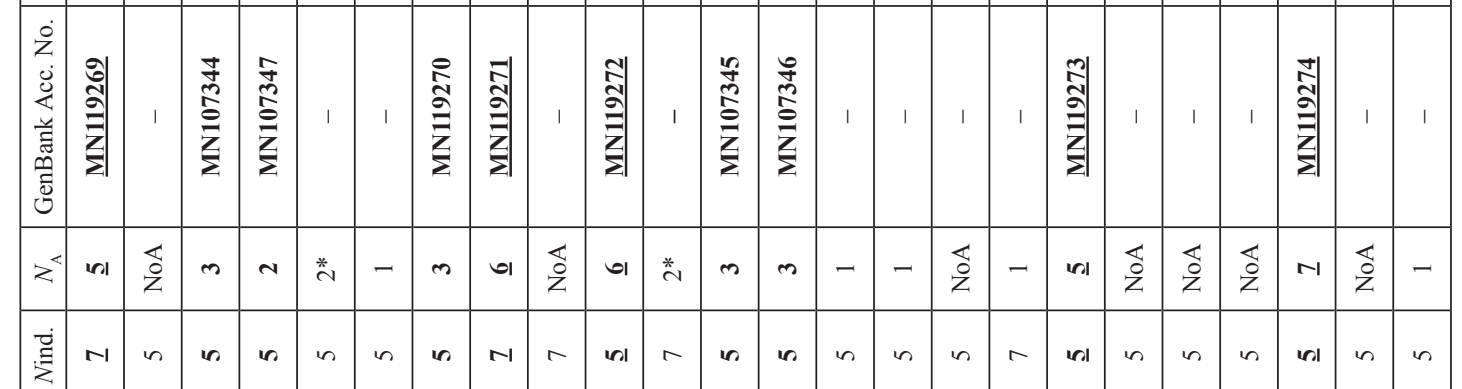

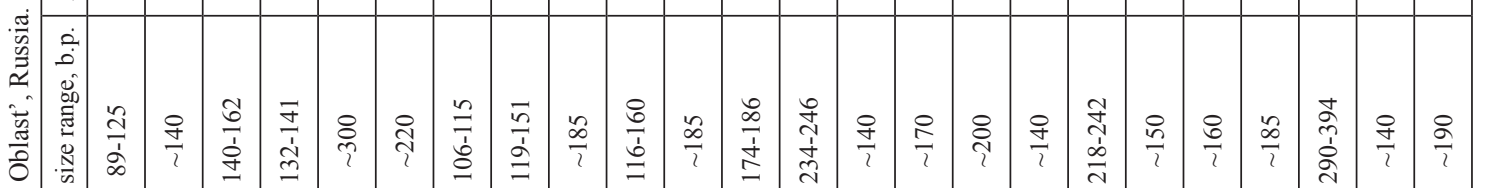


Table 2. Characteristics of 5 highly polymorphic microsatellite loci in Spermophilus fulvus.

\begin{tabular}{|l|c|c|c|c|c|}
\hline \multicolumn{1}{|c|}{ Locus } & $\begin{array}{c}\text { Allele size } \\
\text { range, b.p. }\end{array}$ & Nind & $N_{A}$ & Ho & He \\
\hline IGS bp & $89-125$ & 86 & 5 & 0.733 & 0.762 \\
\hline XmohC10 & $119-151$ & 86 & 8 & 0.872 & 0.821 \\
\hline XmohD116 & $116-136$ & 86 & 6 & $0.767^{*}$ & 0.773 \\
\hline TR4-1 & $218-242$ & 86 & 5 & 0.686 & 0.768 \\
\hline TR4-5 & $290-398$ & 86 & 14 & 0.837 & 0.879 \\
\hline
\end{tabular}

* Significant deviation from Hardy-Weinberg equilibrium. $N$ ind $-N$ individuals tested, $N_{\mathrm{A}}-N$ alleles, $\mathrm{Ho}$ - observed heterozygosity, $\mathrm{He}$ - unbiased expected heterozygosity.

(XmohD116) showed a slight deviation from Hardy-Weinberg equilibrium after Bonferroni correction for multiple comparisons. Exact $p$-values for deviation from HWE were estimated by the Markov chain method with the chain length of 100,000 in the program GENEPOP 4.7 (web version available at http://wbiomed.curtin.edu. au/genepop/; Raymond \& Rousset, 1995; Rousset, 2008).

Pair-wise comparisons performed in GENEPOP revealed significant linkage disequilibrium in two pairs of loci, both including TR4-5 (TR4-5/TR4-1 and TR4-5/ $\mathrm{XmohD} 116, p<0.000001$ and $p=0.004$, respectively, after standard Bonferroni correction for multiple comparisons, $\alpha=0.05 / 10=0.005$ ). This violates the assumption of independence of loci (Selkoe \& Toonen, 2006), and, thus, TR4-5 should be excluded from population genetics analysis to avoid pseudo-replication but is useful for parentage analysis due to its high polymorphism. Its resolving power in parentage analysis is increased by one indel between CCTT and CTTT repeat motifs within this compound microsatellite as revealed by sequencing. In XmohD116 with compound motif GATG+GATA, sequencing revealed size homoplasy (i.e. equally sized alleles with different sequences, Estoup et al., 2002). Though, amplicon size correlates well with SSR repeat number, without taking into account sequence variation, this marker should be used with caution in population genetics, and, especially, in phylogenetic and phylogeographic studies (Barthe et al., 2012).

We conducted preliminary cross-amplification tests for IGS 24D, IGS 110b, XmohC10, XmohD116, D2, and D12 with other two Palearctic ground squirrels, S. major and $S$. suslicus, with 2 individuals in each species. In both species, the product was amplified for all loci tested. Polymorphism was detected in all loci in S. suslicus and in all but one (IGS 110b) in S. major.

To conclude, this set of polymorphic microsatellite markers developed for the first time for Eurasian ground squirrel species will benefit studies of the population genetic structure, parentage pattern, mating system, reproductive success, and interspecific hybridization as well as conservation efforts in S. fulvus and other close-related Palearctic ground squirrels.

ACKNOWLEDGEMENTS. The study was supported by Russian Foundation for Basic Research (19-04- 00577-a). Comments from two anonymous reviewers were very useful.

\section{References}

Barthe S., Gugerli F., Barkley N.A., Maggia L., Cardi C. \& Scotti I. 2012. Always look on both sides: phylogenetic information conveyed by simple sequence repeat allele sequences // PLoS ONE. No.7. P.e40699.

Bell K.C. \& Matocq M.D. 2010. Development and characterization of polymorphic microsatellite loci in the Mohave ground squirrel (Xerospermophilus mohavensis) // Conservation Genetics Resources. Vol.2. No.1. P.197-199.

Estoup A., Jarne P. \& Cornuet J.-M. 2002. Homoplasy and mutation model at microsatellite loci and their consequences for population genetics analysis // Molecular Ecology. No.11. P.591-1604.

Gondek A., Verduijn M. \& Wolff K. 2006. Polymorphic microsatellite markers for endangered spotted suslik, Spermophilus suslicus // Molecular Ecology Notes. Vol.6. No.2. P.359-361.

Hanslik S. \& Kruckenhauser L. 2000. Microsatellite loci for two European sciurid species (Marmota marmota, Spermophilus citellus) // Molecular Ecology. Vol.9. No.9. P.2163-2165.

Jones R.T., Martin A.P., Mitchell A.J., Collinge S.K. \& Ray C. 2005. Characterization of 14 polymorphic microsatellite markers for the black-tailed prairie dog (Cynomys ludovicianus) // Molecular Ecology Notes. Vol.5. No.1. P.71-73.

Kucheruk V.V. 1998. [Present views of Citellus fulvus range] // Zoologicheskii Zhurnal. Vol.77. P.1205-1207 [in Russian].

May B., Gavin T.A., Sherman P.W. \& Korves T.M. 1997. Characterization of microsatellite loci in the Northern Idaho ground squirrel Spermophilus brunneus brunneus // Molecular Ecology. Vol.6. No.4. P.399-400.

Oparin M.L., Oparina O.S. \& Tsvetkova A.A. 2004. Pasture as a factor of transformations of ground ecosystems in semiarid regions // Povolzhskii Ecologicheskii Zhurnal. No.2. P.183-199 [in Russian, with English summary].

Raymond M. \& Rousset F. 1995. GENEPOP (version 1.2): population genetics software for exact tests and ecumenicism // Journal of Heredity. Vol.86. P.248-249.

Rousset F. 2008. Genepop'007: a complete reimplementation of the Genepop software for Windows and Linux // Molecular Ecology Resources. No.8. P.103-106. 
Selkoe K.A. \& Toonen R. J. 2006. Microsatellites for ecologists: a practical guide to using and evaluating microsatellite markers // Ecology Letters. Vol.9. No.5. P.615-629.

Shilova S.A., Savinetskaya L.E. \& Tchabovsky A.V. 2015. Long-term and recent dynamics of the yellow souslik (Spermophilus fulvus, Rodentia, Sciuridae) population from Yeruslan sands of Transvolga region // Zoologicheskii Zhurnal. Vol.94. No.8. P.944-954 [in Russian, with English summary].

Thorington Jr. R.W., Koprowski J.L., Steele M.A. \& Whatton J.F. 2012. Squirrels of the World. Baltimore: Johns Hopkins University Press. 472 p.

Titov S.V., Ermakov O.A., Shmyrov A.A., Kuzmin A.A., Surin V.L. \& Formozov N.A. 2006. Population features of interspecial hybridization of ground squirrels (Spermophilus: Rodentia, Sciuridae) // Bulleten' Moscovskogo Obshchestva Ispytatelei Prirody. Otdel Biologicheskii. Vol.111. P.36-41 [in Russian, with English summary].

Titov S.V., Shmyrov A.A., Kuzmin A.A., Ermakov O.A., Surin V.L. \& Formozov N.A. 2007. [Patterns of dynamics of genetic structure of hybrid populations of mammals (with gen. Spermophilus as a model)] // Rozhnov V.V. (ed.). Molekularno-geneticheskiye Osnovy Sohraneniya Bioraznoobraziya Mlekopitayushchih Golarktiki: Materialy mezhdunarodnoi konferencii. Moskva: KMK Scientific Press Ltd. P.258-269 [in Russian].

Titov S.V., Savinetskaya L.E. \& Tchabovsky A.V. 2009. High genetic diversity in the long-tailed ground squirrel (Spermophilus undulatus) population on Olkhon Island: A natural gene bank or the consequences of long-term isolation? // Doklady Biological Sciences. Vol.429. No.1. P.523-535.

Van Oosterhout C., Hutchinson W.F., Wills D.P.M. \& Shipley P. 2004. MICRO-CHECKER: software for identifying and correcting genotyping errors in microsatellite data // Molecular Ecology Notes. No.4. P.535-538.

Vasilieva N.A. \& Tchabovsky A.V. 2015. A shortage of males causes female reproductive failure in yellow ground squirrels // Science Advances. Vol.1. No.9. P.e1500401.

Vasilieva N.A. \& Tchabovsky A.V. 2018. Reproductive decisions in a "fast-living" sciurid: a case study of the yellow ground squirrel (Spermophilus fulvus) // Biology Bulletin Reviews. Vol.8. No.1. P.12-22. 